\title{
Charter of The Business Historical Society, Incorporated
}

\section{AS GRANTED BY \\ The Commomiealth of flassachusetts}

Be IT Known That whereas

Frederic H. Curtiss, Charles H. Taylor, George Woodbridge,

George A. Rich, Allan Forbes, Edward H. Redstone and John

E. Oldham

have associated themselves with the intention of forming a corporation under the name of

\section{The Business Historical Society, Incorporated,}

for the purpose of the following: - To educate and benefit its members and mankind, and to advance the scientific study and development of finance, trade, commerce, industry and business generally, by research and instruction, by preparing, collecting, preserving and diffusing scientific, literary and historical materials and knowledge relating to business affairs, and by establishing, maintaining and enlarging a business library, independently, or through coöperation with, and donations to, any other charitable, benevolent, scientific, literary or educational institution having any purpose related to any of the purposes of the corporation; to associate and coöperate with and to assist others having similar purposes; and to acquire, utilize, apply and dispose of property and funds exclusively in establishing, maintaining, improving and extending the benefits and usefulness of the corporation through the accomplishment of its purposes, all of said purposes being non-partisan, non-sectarian, charitable, benevolent, scientific, literary and educational and in no manner directly or indirectly for profit or dividend paying to anyone; and in furtherance and not in limitation of any of the foregoing purposes: (I) To stimulate interest in, and investigation and expert study of, the beginnings and evolution of finance, commerce and industry, and alone, or in coöperation with others, to provide for research in this field of inquiry; (2) To collect and preserve alone, or in coöperation with others, a comprehensive collection of books, periodicals, pamphlets, manuscripts and other library items, original records and accounts, maps, documents, data and other material and objects in connection with the financial, commercial and industrial development of the world, and to encourage and assist others in such undertakings; (3) To promote better understanding of the essential unity of financial, commercial and industrial activity throughout the world; its inseparable relation to the welfare of man and its power as an international, intersectional and interclass binding force; to coöperate in work to this end; and to aid 
in the advancement of the science and the profession of business; and (4) To classify, catalogue, index, arrange, annotate and compile, alone or in coöperation with others, the literature, documents and data of finance, commerce, industry and business generally, and to publish, and to coöperate with others in the publication of, the results of research and study, transactions, periodicals, monographs, biographies, statistics, valuable accounts and records and documents pertaining to finance, commerce, industry and business generally and other material within the scope of the foregoing clauses;

and have complied with the provisions of the Statutes of this Commonwealth in such case made and provided, as appears from the certificate of the President, Treasurer, Clerk and Council of said corporation, duly approved by the Commissioner of Corporations and Taxation and recorded in this office:

Now, Therefore, I, FREDERIC W. COOK, Secretary of The Commonwealth of Massachusetts, DO HEREBY CERTIFY that said

Frederic H. Curtiss, Charles H. Taylor, George Woodbridge,

George A. Rich, Allan Forbes, Edward H. Redstone and John

E. Oldham,

their associates and successors, are legally organized and established as, and are hereby made, an existing corporation under the name of

The Business Historical Society, Incorporated, with the powers, rights and privileges, and subject to the limitations, duties and restrictions, which by law appertain thereto.

(THE SEAL OF

COMMONWEALTH

OF MASS.)
Witness my official signature hereunto subscribed, and the Great Seal of The Commonwealth of Massachusetts hereunto affixed, this twenty-sixth day of September in the year of our Lord one thousand nine hundred and twenty-five.
(Signed) F. W. COOK, Secretary of the Commonwealth.

\section{THE FOUNDER MEMBERS OF THE BUSINESS HISTORICAL SOCIETY, INCORPORATED}

Adams, Charles F. Treasurer of Harvard University, 84 State Street, Boston, Mass.

Aiken, Alfred L. 70 Elm Street, Worcester, Mass.

Belden, Charles F. D. Director of the Boston Public Library, Boston, Mass.

Brigham, Clarence S. Librarian, American Antiquarian Society, Worcester, Mass. 